\title{
Negotiating race in post-apartheid South Africa: Bernadette's stories
}

\author{
Zannie Bock
}

\begin{abstract}
Contemporary scholarship on race investigates how racism is deeply embedded in everyday norms and practices in ways which subtly, even unwittingly, serve to reproduce white domination. In South Africa, like many other postcolonial societies, racial constructs continue to be particularly salient. This paper focuses on how a young South African, Bernadette, navigates the complex terrain of racial positioning in a focus group interview with her peers. Drawing primarily on Labov's seminal work on narrative, as well as more recent interactional approaches, it investigates how Bernadette uses the reported speech of others in her stories as a key narrative strategy for racial positioning. The analytical findings suggest that despite her efforts to distance herself from what she perceives as racist talk, she slips into a racializing discourse which is much less overt than that which she rejects, and which has the effect of reassembling the apartheid hierarchy as an explanatory framework. This paper argues that a narrative lens enables the researcher to begin uncovering the multilayered complexities of racial positioning and the subtle ways in which racial discourses circulate in contemporary talk.
\end{abstract}

\section{Introduction}

This paper is about race - or more particularly, the ways in which young people discursively negotiate the complexities of race - in a society which has recently emerged from more than four centuries of colonialism and legalized racial oppression. The context is South Africa, more than twenty years after the transition to democracy and the dismantling of the apartheid system (1948- 1994) which had entrenched white privilege and power. For young people growing up in the "new" South Africa, the terrain of racial positioning is difficult and uneven. Referred to as "born frees," they aspire to be liberated of the past yet are themselves shaped by and positioned within its legacy (Bundy 2014).

Although scholars generally agree that there is no biological basis to racial classifications, race is experienced by South Africans as very real. Why this is so can be explained with reference to history. While racial segregation existed prior to 1948 , racial labels were more variably and flexibly deployed, but with the advent of apartheid, each individual was assigned an inflexible category: "black," "white," "coloured" 1 or

\footnotetext{
${ }^{1}$ The term "coloured" in South Africa, when used to refer to a racial category, has a different meaning to the term "colored" as used in the United States.
} 
"Indian" (Posel 2001). The term "coloured" in South Africa is used to refer to people of complex mixed heritage arising out of a history of colonialism and slavery. Although groups classified "coloured" share a number of linguistic and cultural commonalities with "whites," they were accorded "second class" status under apartheid. While they were granted some privileges (e.g. job preferences, limited voting rights) above those classified "black" (or "African"), they were discriminated against as people of colour, had no meaningful democratic rights and were excluded from the privileges and resources reserved exclusively for those classified "white." As a result of these classifications, notions of race and difference infiltrated every facet of South African life. Taken together with the entire raft of apartheid laws, people were positioned within a racial hierarchy, entrenching "whiteness" as "superior" and "blackness" as "inferior." Being "coloured" meant occupying a rank somewhere in the middle.

Although apartheid officially ended in 1994, the issue of race as a primary marker of identity has continued to permeate many aspects of contemporary public and private life (Seekings 2008). As opposed to the overt and explicit racial classifications legitimated under apartheid, racial identities are still invoked in many subtle ways. This paper investigates how a young "coloured" woman with the pseudonym Bernadette discursively navigates this difficult terrain. It argues that despite her efforts to distance herself from what she perceives as racist talk, her stories are infused with racializing discourses and structured according to the apartheid logic of racial hierarchy and difference.

The analysis of Bernadette's stories is informed by contemporary views on race and identity, which are reviewed in Section 2 below. Section 3 outlines the research methodology and analytical framework, and in Section 4, the data are analyzed using theoretical concepts from Labov (1972), Bamberg and Georgakopoulou (2008) and De Fina and Georgakopoulou (2012, 2015). Section 5 reflects on what the analytical findings reveal about her racial positioning, and explores the value of a narrative approach for this analysis. It argues that a narrative lens enables the researcher to begin "uncovering" the multi-layered complexities of racial positioning and the subtle ways in which racial discourses circulate in contemporary talk.

\section{Literaturereview}

Contemporary scholarship on race points to the lack of conceptual and terminological consensus in the field. This paper is informed by the view that "race" is not a biological category, but rather a social construct, the outcome of historical processes which invest particular physical characteristics (e.g. skin colour) with a range of social meanings (Tate 1997). "Racism" is understood as the ideology of racial superiority which prescribes that "a designated racial group is either biologically or culturally inferior" (Collins and Solomos 2010: 3), and then uses such beliefs to rationalize their domination (Collins and Solomos 2010). Given that race is a product of social interaction, discourse is central to this process of racialization, where "racializing discourses" can be understood as referring to "the actual language use 
(spoken and written) that sorts some people, things, places, and practices into social categories marked as inherently dangerous and Other" (Dick and Wirtz 2011: E2).

Aligned with this social constructionist view of race, this paper understands identity as something constructed and variable, not "fixed," which is shaped by and responsive to the interactional context in which it is performed (De Fina and Georgakopoulou 2012). As much contemporary research has shown, each of us lives with a multiplicity of "potentially contradictory identities [...] Which of them we focus on, bring to the fore, and identify with, depends on a host of factors. At the centre, however, are the values we share or wish to share with others" (Collins and Solomos 2010: 6).

Critical work on race has a long interdisciplinary history, drawing on a number of different traditions including Critical Race Theory (CRT) and Whiteness Studies (Collins and Solomos 2010; Twine and Gallagher 2008). Over the past five decades, this research has moved beyond a focus on the ways in which racism and white supremacy are overtly marked and enacted, to an examination of the ways in which racism - as whiteness - is deeply embedded in everyday norms and practices which work in subtle, often unwitting ways, to reproduce and naturalize white domination. In the remainder of this section, these frameworks are briefly reviewed, and the ways in which they have shaped research on language and race in South Africa are explored.

CRT emerged among African-American legal scholars in the 1970 s as a form of political activism for racial justice. It challenged the discourse of "equal opportunity" associated with the 1960s Civil Rights Movement, the effect of which, it argued, was to deflect attention away from the ways in which dominant institutional and social structures continued to protect and reproduce white privilege and power (Tate 1997). It thus put the spotlight firmly on the structural nature of racism and the universalizing power of white experience and judgment.

Black scholars in the United States were also central to the emergence of "Whiteness Studies" in the 1990s (Twine and Gallagher 2008). This investigates the contextspecific ways in which whiteness as a form of power is deployed and performed, and the cultural practices and discursive strategies used to render white power invisible. As for CRT, Whiteness Studies include accounts of how "colour blindness as a political ideology is increasingly used to negate institutional racism" (Twine and Gallagher 2008: 9); how "cultural deficit arguments" are used to explain away racial inequality; and how "appeals to nationalism" may serve to mask reactionary politics (Twine and Gallagher 2008: 9). Whiteness Studies also recognizes that race is only one of many factors to shape individual and group identities, and that race intersects with other social factors (such as gender and class) in complex ways to position people in relation to others. 
CRT and Whiteness Studies have had a profound impact on research both globally and locally, particularly with regard to what is commonly termed "new racism" (Collins and Solomos 2010). In South Africa, it has informed significant work on racializing discourses post-1994 (Ansell 2004; Steyn 2004; Walker 2005; Steyn and Foster 2008). Using data from written submissions, media texts and focus group interviews, these scholars describe what Steyn (2004) refers to as "white talk," namely a way of speaking which enables white South Africans to defend their continuing privilege without opening themselves to the criticism of racism. Their analyses describe the discursive repertoires speakers use to present themselves optimally, even as they express sentiments which are resistant to the processes of transformation. While expressing explicit commitment to the values of democracy, non-racialism, and so on, they avoid questions of inherited structural inequality by presenting everyone as "equal" - "equally responsible, equally affected, equally able” (Steyn and Foster 2008: 31).

Although these scholars acknowledge that white talk does not refer to a single homogeneous discourse, I would argue that their analyses tend to produce a rather static, bifurcated picture of racializing discourses in South Africa (e.g. Steyn's "white talk" and Ansell's "two nations of discourse" - one black, one white). The analysis in this paper seeks to complicate this picture by showing how racializing discourses circulate across racial groups, and asks whether in fact this talk is not better seen as part of a repertoire of discourses which are strategically deployed by a range of South Africans, not only those who identify as white.

\section{Research methodology and data}

This paper investigates how one participant in a focus group positions herself as a racial subject in a post-apartheid South Africa. The participants are a close-knit group of five students - two men, three women - at a higher education institution. They were selected by the facilitator (who is herself a student) and they all selfidentify as coloured. The interview includes anecdotes about their parents' experiences of life under apartheid, their parents' views on other races, their own experiences of racism, and their fears and anxieties about their place in a postapartheid South Africa. All fear exclusion from jobs on the basis of their race, and they invoke the oft-quoted dictum that as coloureds they are still caught "in the middle": while they were not white enough under apartheid, they are not black enough now to qualify for job preferences and other redress measures.

Despite the fact that this is a focus group interview, their interaction is more akin to casual conversation, with highly interactive turn taking and co-constructed evaluations. As Lambrou (2003: 171) has argued, when the participants in a focus interview are friends, conversational story telling becomes "an inevitable feature" as wellestablished patterns of convivial interaction "take over." The fact that they all share a racial identity adds to their lack of inhibition: research shows that talk in racially homogeneous groups differs from that in multiracial ones. While the former is more

\section{http://repository.uwc.ac.za}


"frank" and stigmatizing, the latter is more "careful" and non-racial in stance (Bock and Hunt 2015; Lefko-Everett 2012). In line with standard ethical requirements, all participants signed consent forms.

The data are based on a transcript of an hour-long interview held in 2013 and were elicited by open-ended questions which asked participants what they knew about apartheid, how they felt about being "coloured," and how racism had affected them. Given the complexities and ambivalences inherent in racial positioning, I elected to work with "stories" as my primary analytical lens. Narrative analysis, I argue, can "unpack" the subtle ways in which speakers discursively "race" themselves and others. For example, the analysis shows how Bernadette uses the reported speech of others as a key narrative strategy to construct her racial position. This allows her to "animate" a position without having to "author" it as her own (Goffman 1981). It also shows how, despite her efforts to distance herself from what she perceives as racist talk, she slips into racializing discourses which are much less overt than those she rejects, and which have the effect of reassembling the apartheid hierarchy as an explanatory framework. My analytical framework draws on two narrative traditions, namely Labov's (1972; Labov and Waletsky 1967) seminal work on narratives of personal experience, and more recent work by scholars who argue that people use stories to "create (and perpetuate) a sense of who they are" (Bamberg and Georgakopoulou 2008: 379) both in the interactional moment as well as in terms of the broader master narratives which constitute their context (Bamberg and Georgakopoulou 2008). Labov's framework is useful in that it draws attention to the role of reported speech as an evaluative device in the narrative structure, while Bamberg and Georgakopoulou (2008) and De Fina and Georgakopoulou's (2012) work on "positioning" show how stories are interactively achieved and contextually situated. Thus, although these approaches are sometimes presented as alternatives (see Bamberg 2007 on "big" or "small" stories), I have found their dual lens productive for this analysis.

Labov's oral narrative framework is well known. It includes six parts, some of which are optional. A typical narrative may begin with an abstract, which summarizes the story or encapsulates the main point of the story. This may be followed by an orientation, which serves "to identify in some way the time, place, persons, and their activity or the situation" (Labov 1972: 364). Orientation clauses may also be dispersed through the story, often for narrative or evaluative effect. Next is the central and most important element, the complicating action, a series of events which disrupts the normal order of things set out in the orientation and culminates in a crisis or high point which the resolution stage in some way resolves. The evaluation of the events, argues Labov (1972: 366), is what gives the story its significance and makes it worth telling. Evaluations may appear in many different forms and at many different points in the narrative, although they typically occur as a separate stage just after the climax, at the end of the complicating action and just before the resolution. The final stage of the framework is the optional coda, an additional element after the resolution which is

\section{http://repository.uwc.ac.za}


a "functional device for returning the verbal perspective to the present moment" (Labov and Waletsky 1967: 39) and which "may also contain general observations or show the effects of the events on the narrator" (Labov 1972: 365). Evaluation, according to Labov (1972), creates a second layer, forming "waves [...] that penetrate the narrative" Labov (1972: 369). His framework includes a range of evaluative devices, from those moments when the narrator "steps outside" the narrative action to comment on its significance, to those which are realized within the syntactic structure of the clause, such as comparison, repetition or intensified lexis. Of significance to this paper is his category of embedded evaluation - reported speech or thought - which, he argues, is a strategy used by narrators to appraise the action, thereby expressing their own attitudes and positions.

Although Labov has been criticized for failing to take into account the interactional context and co-constructed nature of narrative, his work is still regarded as ground breaking (Schegloff 2003). Contemporary approaches, however, have shifted the focus onto the multiplicity of narrative forms and functions, and how narratives are embedded within social practices and discourses (De Fina and Georgakopoulou 2015). These scholars examine "how shared ideologies and stereotypes about social categories of belonging" (De Fina 2008: 422) become a resource for local self and other identity positionings (De Fina 2008). They also show how speakers may use stories as exemplums to back up their arguments. These "experience-based" claims, they argue, acquire a validity which is harder to refute than ones based on rational argument (De Fina and Georgakopoulou 2012).

The analysis in this paper explores how Bernadette uses the reported speech of others as a key narrative strategy to express her own complex positioning. By presenting herself as simply the animator of others' voices, she is able to signal alignments (or disalignments) without having to explicitly claim these positions as her own, thereby achieving a more ambivalent and nuanced stance.

\section{Data analysis}

In 2013, Bernadette was a postgraduate student studying Industrial Psychology at a South African university. Although she grew up in a historically coloured, working class area of Cape Town and attended local schools as a child, her single mother managed to send her and her sister to a better resourced, English-medium high school in a historically white area nearby. She is a high achiever academically and a dominant participant in this interview, presenting herself as well informed and self-assured. Although she would have grown up hearing and speaking the local mixed variety of Afrikaans, Kaaps, she chooses in this interview to speak English only, even when the other participants code switch or use predominantly Afrikaans for their contributions. In the analysis, I suggest that this may be because she is careful to present herself as an aspirant middle-class professional, which in the South African context is associated with speaking English (Anthonissen 2013). 
In the first two stories, Bernadette refers to childhood episodes which serve to establish the kind of overt racism from which she is anxious to distance herself. The third story refers to a recent past and is, I would argue, the most complex and interesting. The last story refers to an event which would have taken place several years before she enrolled at university, when she went to work in a bank for a year. Taken together, these stories give us a sense of Bernadette's racial positioning as well as the discourse she is negotiating.

In Story (1), Bernadette recounts how she first became aware of race through the stories of her parents and grandparents. Here, the innocence of childhood is equated with "not seeing" race, these categories only becoming "visible" when she was inducted into the world view of her parents and grandparents, whom she constructs as suspicious of and antagonistic toward other races, and of reproducing a discourse of racial othering. ${ }^{2}$

This story recalls her becoming aware of how the adults in her environment spoke about other races, in this case, "blacks". The expression jinne is a mild Afrikaans expletive with an equivalent meaning to 'gosh' or 'crikey' in English. The term "darkies," however, is a racist term for "blacks," thereby interpellating black people as inferior in the racial structuring of the young Bernadette. Note that the reaction of the focus group participants is to laugh - perhaps because they recognize this discourse as that of their own parents, or even themselves - but that Bernadette is at pains to reject it and position herself as different to her grandmother. She achieves this through the overt rejection of these ways of speaking in line 8 ("you don't use these"), to which Heather responds that people do in fact still speak like this (line 9) and Paulo admits that it is not only the older generation but that "we also use it", where "we" can be assumed to be a reference to himself, his family and friends (line 11).

\footnotetext{
${ }^{2}$ The transcript is divided into clauses and arranged, following Hymes's ethnopoetic principles (Blommaert 2007), in a manner which seeks to reflect the equivalences and forms which provide an underlying structure to the narrative. Parallelisms and repetitions are underlined, emphatic speech is presented in caps and the reported speech is in single quotation marks. Translations from Afrikaans as well as paralinguistic information are given in square brackets and the Labovian stages are numbered and labelled. (See the appendix for a complete list of the transcription conventions.)
} 
(1) "Jinne die darkies"

1. (Orientation)

1. My first my first two primary schools were coloured

2. and my third one we had uhm BLACK kids as well

3. but at that point I didn't ... and we had white kids

4. so I didn't KNOW that it was that they were black and they were white they were just my friends like they were just THERE

\section{2. (Complicating Action)}

5. but then you start listening to the way your parents talk your grandparents talk

6. and my gran would be like 'jinne die darkies' [gosh, the blacks]

7. [all laughing]

\section{3. (Evaluation)}

8. Bernadette: and I would be like 'you don't use these'

9. Heather: DIT is so! ander woorde ook [It is like that! other words as well]

10. Bernadette: and they STILL USE IT they still use it like

11. Paulo: ons gebruik dit ook [we also use it]

12. Bernadette: ja hey it is how it is ... and

13. but it never really resonated with me

14. and I never thought much of it

While Bernadette acknowledges this practice as common, she continues to distance herself from it (and the shared stance of her co-participants) with the statement, "but it never really resonated with me" (line 13), an explicit rejection of this discourse and its underlying racist ideology. In other words, in this story, she constructs herself as a young girl who made friends with all classmates irrespective of race, and who was unaware of racial distinctions until she was discursively inducted into them by her grandmother. Here she is at pains to position herself as "not racist" and as having moved beyond the prejudiced mindset of her elders.

Stories (2) and (3) are told in sequence by Bernadette in response to a question posed by the facilitator as to whether the participants felt being coloured had "hindered" them in any way. They understood this question as "have you ever felt racially discriminated against" as it triggered a long discussion, including a recount of an incident at a public fair where a number of them were at the receiving end of overtly racist behavior at the hands of the white playground owners who made it uncomfortable for them to join one of the rides. 
In Story (2), Bernadette recounts an early experience of racism: it recalls an event which must have occurred in the early 1990 s when she was still a child, and a process of political change had become inevitable with the release of Nelson Mandela and the unbanning of the African National Congress.

(2) The white woman of Wynberg

1. (Abstract)

1. Bernadette: may I just say something ...

2. [everyone laughing]

3. there nuh I was ...

4. two stories 
5. when I was a child

6. when we came from the hospital

7. and we were going

and this is a largely white area

it's in Wynberg where the military uhm families live

8. and my mommy decided

it's so hot

we're going to swim

9. she's gonna take me to the pool there

10. but it's a WHITE area

11. but because my father is in the navy

we have access

we can go and explore

\section{3. (Complicating Action)}

12. and then this we walking past this lady's yard

13. and I said something about the dog because the dog is so cute

14. and then she came out with her

15. sy kom met haar besemstok $=$ [she came with her broom]

16. Dwayne: $=$ oh snap $=$

17. Bernadette: = and she's like 'fokof hiervandaan' ['fuck off from here'] because uhm 'kom vat julle nou hier ook oor' ['are you coming to take over here as well']

\section{4. (Evaluation)}

18. [Heather gasping]

19. Bernadette: like YES

and we were just walking by

we weren't even doing anything

we were just on our way to the pool

\section{5. (Resolution)}

20. so my mommy's like 'let's rather go home

because if this is the type of people who live HERE

then what can we expect

21. [Dwayne mumbling]

22. Bernadette: ja at the pool' 


\section{6. (Coda)}

23. but then [laughing] then again you don't

24. as a child you just so like shocked

25. like why would she go on like that?

26. [Interviewees grinning in agreement]

27. Bernadette: you didn't notice that this woman is white

you know that she's white

but you didn't understand what was going on.

In the first stanza, Bernadette indicates that she wishes to tell two stories, with her bid for a speaking turn forming the abstract. In stanza two, her story begins where she introduces herself as a young girl, this time in the company of her mother, who wishes to take her to a public pool in a suburb of Cape Town called Wynberg. During the apartheid years, Wynberg was declared a "whites only" residential area. However, as Bernadette explains, her family had certain privileges as her father worked in the navy and so they "had access" to the whites' only public pool. Her narrative purpose here is to emphasize that this is a "white area" (repeated in lines 7 and 10), the reasonableness of their desire for a swim ("it's so hot"), and the rights that they had to be in this otherwise racially exclusive area ("we have access/we can go and explore"). It is also significant that she switches into the historical present in line 7 when she mentions that Wynberg is a white area, as though it is this point that she is caught up in the drama of her telling (Schiffrin 1981).

In the third stanza, the complicating action unfolds as Bernadette stops to admire a cute dog - an action which frames her as young, innocent and simply enjoying a day out with her mother - and is accosted by the dog's owner who comes out of her house with a broom and shouts obscenities at the girl and her mother, sparking, in Labov's (1972) terms, the crisis or high point of the narrative. Note that she does not need to mention the race of the woman: from her careful setting up of the scene in the orientation, this information is immediately evident to her audience. Similarly, her shift into Afrikaans at this point is also interpreted as indexing whiteness as Dwayne immediately responds with "oh snap" (meaning, 'oh gosh'). Bernadette then switches between English and Afrikaans for the rest of this stanza, reserving a particularly crude Afrikaans for the white woman, thereby characterizing her as offensive and rude, and identifying her with a discourse associated with white racists who feared the transition to a black majority government and the dismantling of the apartheid laws which privileged whiteness (Bock 2011). The act of switching into Afrikaans at this point, as well as the continued use of the historical present tense, enables Bernadette to create narrative immediacy and authenticity, thereby positioning her current audience as observers of the event (Schiffrin 1981) and giving her account "eye-witness" status to back up her claim of racism (De Fina and Georgakopoulou 2012).

In stanza 4, the event is evaluated by Heather's reaction of horror and disbelief (gasping) and Bernadette's reiteration of their innocence, accentuated by the syntactic parallelism of clauses in line 21: “we were just walking by/we weren't even doing anything/we were just on 
our way to the pool". Against the normality of this assertion, the behavior of the woman is construed as unmotivated by anything other than racial hatred and mistrust. Bernadette's evaluation serves to suspend the action at this point, thereby heightening the narrative tension in classic Labovian style.

In stanza 5 , her mother resolves the crisis by suggesting that they leave the contested white space and return home as they are clearly unsafe and unwelcome. Here the reasonableness of her mother's voice is set in contrast to the blatantly racist voice of the white woman, a narrative choice which allows Bernadette to clearly distance herself and her mother from the white woman's racism.

Stanza 6 acts as a coda in that the narrative perspective changes from the immediacy of the telling to a more distanced evaluative one. This shift is signaled by her laughter, and her use of the past tense and the generic "you" (as opposed to the "we" of the previous stanzas). Bernadette recalls her incomprehension of this event, once again, asserting, as in Story (1), her inability to understand race as significant or meaningful as a child. Her evaluative emphasis is once again marked, as in line 19, by the parallelism in the syntactic structure ("you didn't notice that this woman is white/you know that she's white/but you didn't understand what was going on").

In both Stories (1) and (2), then, Bernadette recounts how race is discursively constructed by adults in her environment, both at home and in the broader society. In both cases, she constructs her childhood self as innocent and unseeing of the racial positions these discourses perpetuate, and is at pains to reject or distance herself from these ways of speaking. In both stories, the high point of the complicating action is realized through the quoted speech of others (her grandmother or the white woman). She does not, however, question the racial categories as such and reproduces them uncritically in her own discourse.

In Story (3), the beginning of which follows on from Story (2) without a pause, her positioning is more complex and difficult to read. It is clear from the start of Story (2) (line 4) that Bernadette had planned to tell both stories in response to the facilitator's question, "has being coloured hindered you in any way". They both encapsulate something about how she has felt negatively interpellated as a racial subject at different points in her life, and she uses these stories, I would argue, to present herself as having moved beyond the old apartheid categories and ideologies of race.

Story (3) is set in the recent past and recounts an incident in the bank when Bernadette again felt negatively positioned, this time by a "black" woman. As for Story (2), she quickly shifts into the present tense (line 3) as she becomes caught up in her role as narrator. Once again, the story can be analyzed as a full narrative of personal experience. In the transcript below, the stanzas' boundaries follow the Labovian structure with stanza 1 providing the orientation, stanzas 2 and 3 recounting two episodes in the complicating action, stanza 4 offering the evaluation, stanza 5, the resolution, and stanza 6 , the coda.

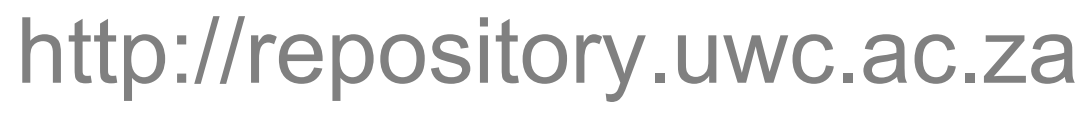


(3) In the bank with my cousin's daughter

1. (Orientation)

1. Bernadette: then the other day I was in the bank

2. and I was sitting and waiting for my sister

3. and my cousin's daughter is with me

4. and she's like two years old

5. BUT she looks WHITE

she has blue eyes

she has that curly blonde hair

and she's very very very fair

she looks like WHITE

6. but she's coloured

7. Heather: $\mathrm{mhm}$

8. Bernadette: and I'm playing with her

\section{2. (Complicating Action)}

9. then this young white guy comes

10. and sits next to me

11. and he's like red as a tomato but anyway

12. and he's talking to me

13. and we're having this lovely conversation just like about random things

14. and then this black woman comes

15. and she stands

16. as the line is moving forward she ends up standing next to us

17. and her daughter goes and sits opposite us

18. and she tells her daughter

I think they call it itomisane something like that

19. and then she like uhm 'mmm, look it's nice hey, it's nice'

20. [Participants laughing] 


\section{3. (Evaluation)}

21. Bernadette: basically saying that it's nice that I'm with this WHITE guy and we have this WHITE child

22. Heather: oh

23. Bernadette: that's what she was THINKING

\section{4. (Resolution)}

24. I was like he looks at me

25. and I look at him

26. and we just start laughing

27. because we know what she's saying=

28. Heather: $=u h=$

29. Bernadette: =and she was looking at me smiling like the happiest like broadest smile ever

30. [Dwayne laughing]

31. Bernadette: 'did you SEE, mmm it's nice' [laughing]

\section{5. (Coda)}

32. so they attach this thing to the white person

33. where it's almost as if you have to feel ... so grateful=

34. Paulo: =ja

35. Bernadette: or how can I say you should feel kwaai [cool] like we would say

36. because you're with a white guy

37. Dwayne and Paulo: [mhm]

38. Bernadette: or when you with a white girl

39. when in actual fact it's ... really not

40. [all laughing]

The orientation introduces Bernadette again as the main character, but now the time period has shifted to "the other day" when she, as a young adult, is old enough to be mistaken for the mother of her cousin's daughter. She uses this orientation to set up a contrast between the coloured identity of her cousin's daughter (and by implication, herself) and the "whiteness" of the child's appearance. These details recall how, in Story (2), Bernadette also used the orientation to set up a contrast between the whiteness of Wynberg and the presence of her mother and herself as coloured people in this contested space. Just as she and her mother had certain privileges which blurred the boundary between coloured and white in the apartheid era, so too the racial categories in this story are presented as "not clear-cut." The reiteration and emphasis of "white" and its classically European features (blond hair, blue eyes) in line 5 signal the ambiguity inherent in the historical positioning of many people classified coloured under apartheid, as well as, perhaps, an aspiration on the part of Bernadette to move beyond these categories and claim a more "privileged" or even 
"post-racial" position in the present. Although she appears to be trying to deconstruct the categories (by drawing attention to their arbitrariness), the analysis shows how, in fact, she moves back into them as the story progresses.

The beginning of the complicating action is signaled by the use of the adverbial "then" as she recalls how a "young white guy" comes into the bank and sits next to her. Unlike the white woman of Story (2), however, he does not abuse her with racist invective; rather he appears to enjoy talking to her as "we're having this lovely conversation just like about random things" (line 13). Although the casual nature of the conversation signals a conviviality and social equality which was completely absent in the previous encounter, Bernadette is careful to reject any suggestion that she might have found the young man (and his white skin) in any way desirable with her disclaimer: "he's like red as a tomato" (line 11).

The arrival of the "black woman" and her daughter initiates a new episode in the complicating action signaled discursively again by "then" (line 14). Bernadette takes five clauses to describe how the woman and her daughter move up the line toward them, allowing for a suitable build-up to the climax of her story, which is the words of the woman quoted as: "mmm, look it's nice hey, it's nice" (line 19). Here she mimics a stereotypical black accent for the woman, thereby caricaturing her as a "typical black subject" of lower social standing. Her inaccurate attempt to repeat the isiXhosa word for "girl" (intombazana) acts as a further distancing mechanism. At this point, her fellow participants laugh, perhaps at the caricature of the black woman, or perhaps because they recognize this kind of situation. Either way, their laughter expresses alignment with her stance.

Why she takes such offence at this statement becomes clear in the next stanza, the evaluation, which suspends the narrative at the high point of the story and allows her to reflect on the significance of the events. According to the interpretation she offers in line 21, she reads the woman as signaling that she, Bernadette, has done well for herself by marrying "up" the racial hierarchy and producing a child who looks white. Her repetition of "white" in the same line serves to reinforce her reading of this statement. Just as she felt interpellated as a racial subject by the white woman of Wynberg, so too, in this story, she feels positioned by the black woman in the racial hierarchy as a "second class citizen." Her positioning in both Stories (2) and (3) is achieved through the weaving together of competing voices, with reported speech used to construct a racialized identity for both women. In both cases, these quotations mark the crisis in the complicating action and serve to suspend and evaluate the narrative action. ${ }^{3}$

\footnotetext{
${ }^{3}$ This event could be interpreted in other more obvious ways. For example, the black woman might simply have been pointing out a cute little girl to her own child, or alternatively, commending Bernadette and her companion for being a mixed-race couple in the new "rainbow nation."
} 
In the resolution, she recounts how she and the young man shared her evaluation of the event. Her description of how they look at each other and laugh knowingly indicates that for her the racial alignment has shifted. No longer is the binary "white" versus "coloured" as in Story (2); now her "we" includes her and the "white guy" united in laughter at the black woman. Toward the end of this resolution, she reiterates her caricature of the woman as foolish and somehow childish ("she was looking at me smiling like the happiest like broadest smile ever") and again mimics the offending words to laughter from her co-participants.

In the coda, Bernadette again reflects on the event and returns the narrative to the present. She once again reiterates her rejection of the imposed hierarchy which elevates whiteness, but in doing so, generalizes the values "they" attach to whiteness, where "they" presumably refers to "blacks" (line 32). This statement prepares the ground for the racial polarizing that continues in line 35 where she explicitly claims a coloured identity for herself with her insertion of kwaai, a local Kaaps word for 'cool' and an index of "colouredness," and her use of the inclusive pronoun, "we," where "we" refers to the users of the word kwaai.

The reading that Bernadette gives the event is quite unusual and points, I would suggest, to her own racial and class anxieties. As much contemporary research argues, social identities are multifaceted and race interacts with other social variables such as gender and class in complex ways (Cho et al. 2013). The way in which she aligns herself with "the white guy" but rejects the "black woman" can be read as a desire on her part to associate with the middle-class privilege indexed by whiteness in the new South Africa where whiteness is still associated with greater symbolic capital and social status. As noted earlier, her insistence on speaking English only in this focus group suggests a socially mobile aspiration.

The experience of being caught "in the middle" is again represented in Story (4). Here Bernadette recounts a recent event when she was once again at the receiving end of racial discrimination, this time in the name of affirmative action or Black Economic Empowerment (BEE). She recounts how a coloured friend of hers at the bank was overlooked for a permanent position despite her greater work experience because she was "not black enough". In terms of South Africa's employment equity policy, racial quotas are applied in many jobs. Bernadette uses this narrative to support her argument that coloureds are still discriminated against in the post-apartheid South Africa. 
(4) Not black enough

1. (Abstract)

1. Facilitator: So the thing we're moving towards is basically you are employed because you are a BEE applicant and not because of your skills

2. Bernadette: No it's the TRUTH

let me tell you this

it's the TRUTH

3. Dwayne: $\mathrm{mhm}$

4. Paulo: $\mathrm{mhm}$

5. Bernadette: it's proven

6. I had to - I

7. Well look here my friend couldn't get the permanent position right?

\section{2. (Orientation)}

8. both working in the bank

9. and then we find the person who got the permanent position she has NO EXPERIENCE ...

10. my friend has all the experience

11. we had three years' experience

12. and she couldn't get the permanent position

\section{3. (Complicating Action)}

13. they brought in this person

14. and then we asked our manager

look what can she do right for next time to get to make sure she gets the position

15. 'sorry we had to choose someone who's black'

16. THAT was his exact words

17. [I'SORRY we had to choose someone who is black'

18. Dwayne: [[hoekom is dit so? [why is it so?]

\section{4. (Resolution)}

19. Bernadette: THEN $\underline{I}$ have to train this person ...

20. but ... knowing that I would never qualify for that position

21. because I'm not black

In this narrative, the Labovian stages are less clear-cut as Bernadette moves back and forth between her evaluation of the event ("my friend couldn't get the permanent position") and the narrative action in lines 13, 14 and 15. She offers her story as evidence in support of the facilitator's statement that "basically you are employed because you are a BEE applicant and not because of your skills". In the abstract, she claims the floor with an emphatic repetition of "it's the truth" and "it's proven" in relation to this statement and sums up the key evaluation of her story, namely that her colleague "couldn't get the permanent 
position" because she was "not black enough". The orientation introduces herself and her friend as colleagues at a bank, but focuses again on her evaluation of the outcome of the story and the fact that the person who did get the job had "no experience". As with her previous stories, the evaluation works with repetition and syntactic parallelisms. The complicating action describes them asking the manager what they should do to ensure they were considered for the next available position, the climax of which is realized, as with her other stories, through the quoted speech of another, this time the manager, who explains that racial criteria have disqualified them from the position ("sorry we had to choose someone who is black"), to which Dwayne responds, "why is it so?". In the resolution, she describes how the narrative is concluded, by her having to train the new appointee, and how this compromises her. This story functions, then, as an exemplum of her experience of racism and her frustration at the fact that the racial hierarchy, now "reversed" in an attempt to undo the long-term effects of apartheid, has had the effect of ascribing her an identity of "not black enough" and reinserting her into a position of disadvantage.

\section{Conclusion}

Bernadette's stories differ in terms of their historical contexts as well as their presentations of self as "seeing" and "knowing" race. With Story (1), she acknowledges that racism is prevalent in her own family, but in her evaluation of both Stories (1) and (2), she constructs herself as having "moved beyond" this kind of talk. The racializing discourses in both stories are easy to identify - they are carried by overtly racist terms and code switches which index discredited racist talk. In Story (3) the positioning is far more complex: here she feels negatively interpellated as a racial subject, a positioning she resists by overtly challenging and rejecting the apartheid hierarchy which privileges whiteness. However, in seemingly rejecting this hierarchy, the analysis shows how she slips unnoticed back into these very frames. While attempting to distance herself from racist discourses, she re-inscribes the "black woman" as inferior and inserts herself into a complex racial matrix based on the apartheid hierarchy.

Stories, I would argue, provide telling insights into the subtle ways in which speakers discursively "race" themselves and others. The narrative analysis in this paper shows how Bernadette uses reported speech and code switching as narrative devices to weave a complex web of racializing perspectives into her story. This strategy allows her to achieve a layered, often ambivalent, positioning which echoes the racialized voices of others without her having to explicitly claim them as her own. By presenting herself as "animator only," her stories serve to re-inscribe racial hierarchies and differences while simultaneously enabling her to sidestep any criticism of racism.

Bernadette's stories illustrate the complexities of "being coloured" in South Africa today. However, she is certainly not alone in mobilizing these discourses. Bock and Hunt (2015) show how racialized talk is part of the discourses of students from across the demographic range who all express fear at being discriminated against

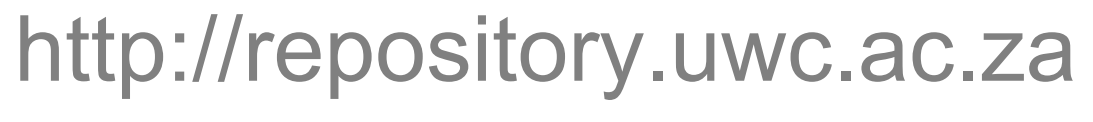


on the basis of their race (see also Bock 2017). As noted earlier in this paper, research on language and race in South Africa has tended to focus on the racializing effects of "white talk." What this case study shows is that these discourses are part of a repertoire which all South Africans may strategically deploy on different occasions. After all, the continued salience of racial talk is not unexpected in a country which has reinvigorated racial categories in the name of redress and affirmative action. Within a context of high unemployment and social instability, it is hardly surprising that racism persists in many different forms. And while South Africans may have become more careful of the way they speak, racist discourse, as Walker argues, "mutates but does not disappear" (Walker 2005: 140). Understanding how race continues to circulate in different and evolving discursive forms is, I would suggest, part of the project of dealing with the legacy of apartheid and building a more socially just society. As Dick and Wirtz (2011) argue, understanding "discursive and other semiotic practices that covertly racialise actors, places, things, and practices [is] key to understanding when, how, and why race continues to matter" (Dick and Wirtz 2011: E2).

\section{Acknowledgements:}

Sincere thanks to Chanel van der Merwe and participants for permission to use their data. Thanks also to Brigitta Busch and Jim Collins for their insightful comments on this data.

This research was made possible by funding from the National Research Foundation (NRF) of South Africa. Opinions, findings, conclusions and recommendations expressed in the article are those of the author and the NRF does not accept any liability in this regard.

\section{Appendix: transcription conventions}

words
WORDS
'words'
[gosh]
[Dwayne mumbling]
$=$
[I
$!$
$?$
-.
-

parallelisms and repetitions

emphatic speech

reported speech

translations from Afrikaans

paralinguistic information

latching

simultaneous speech

'surprised' intonation

'uncertainty' (rising intonation)

short pause

false start 


\section{References}

Ansell, A. 2004. Two nations of discourse: Mapping racial ideologies in post-apartheid South Africa. Politikon 31(1). 3-26.

Anthonissen, Christine. 2013. 'With English the world is more open to you': Language shift as marker of social transformation. English Today 29(1). 28-35.

Bamberg, Michael. 2007. Stories: Big or small - Why do we care?. in Michael Bamberg (ed.), Narrative: State of the art, 165-174. Amsterdam: John Benjamin Publishing.

Bamberg, Michael \& Alexandra Georgakopoulou. 2008. Small stories as a new perspective in narrative and identity analysis. Text and Talk 28(3). 377-396.

Blommaert, Jan. 2007. Applied ethnopoetics. in Michael Bamberg (ed.), Narrative: State of the art, 215-224. Amsterdam: John Benjamin Publishing.

Bock, Zannie. 2011. Code-switching - An appraisal resource in Truth and Reconciliation Commission testimonies. Functions of Language 18(2). 183-209.

Bock, Zannie. 2017. "Why can't race just be a normal thing?" Entangled discourses in the narratives of young South Africans. in Caroline Kerfoot \& Kenneth Hyltenstam (eds.), Entangled discourses: South-north orders of visibility, 59-76. New York: Routledge.

Bock, Zannie \& Sally Hunt. 2015. 'It's just taking our souls back': Apartheid and race in the discourses of young South Africans. Southern African Linguistics and Applied Language Studies 33(2). 141-158.

Bundy, Colin. 2014. Short-changed? South Africa since Apartheid. Auckland Park: Jacana Media.

Cho, Sumi, Kimberlé Williams Crenshaw \& McCall. Leslie. 2013. Toward a field of intersectionality studies: Theory, applications, and praxis. Signs 38(4). $785-810$.

Collins, Patricia Hill \& John Solomos. 2010. Introduction: Situating Race and Ethnic Studies. In Patricia Hill Collins \& John Solomos (eds.), The SAGE Handbook of Race and Ethnic Studies, 1-16. London: Sage.

De Fina, Anna. 2008. Who tells which stories and why? Micro and macro contexts in narrative. Text and Talk 28(3). 421-442.

De Fina, Anna \& Alexandra Georgakopoulou. 2012. Analyzing Narrative: Discourse and sociolinguistic perspectives. Cambridge: Cambridge University Press.

De Fina, Anna \& Alexandra Georgakopoulou (eds.). 2015. The handbook of narrative analysis. Oxford: Wiley-Blackwell.

Dick, Hilary Parsons \& Kristina Wirtz. 2011. Racialising Discourses. Special issue of the Journal of Linguistic Anthropology 21. E2-E10.

Goffman, Erving. 1981. Forms of talk. Oxford: Blackwell.

Labov, William. 1972. Language in the Inner City. Philadelphia: University of Pennsylvania Press.

Labov, William \& Joshua Waletsky. 1967. Narrative analysis: Oral versions of personal experience. In June Helm (ed.), Essays on the verbal and visual arts: Proceedings of the 1996

Annual Spring Meeting of the American Ethnological Society. 12-44. Seattle: University of Washington Press.

Lambrou, Marina. 2003. Collaborative oral narratives of general experience: When an interview becomes a conversation. Language and Literature 12(2). 153-174. 
Lefko-Everett, Kate. 2012. Leaving it to the children: Non-racialism, identity, socialisation and generational change in South Africa. Politikon 39(1). 127-147.

Posel, Deborah. 2001. What's in a name? Racial categorisations under apartheid and their afterlife. Transformation $47 \cdot 50-74$.

Schegloff, Emanuel. 2003. 'Narrative analysis': Thirty years later. in Christine Bratt Paulston \& G. Richard Tucker (eds.), Sociolinguistics: The essential readings, 105-113. Oxford: Blackwell.

Schiffrin, Deborah. 1981. Tense variation in narrative. Language 57(1). 45-62.

Seekings, Jeremy. 2008. The continuing salience of race: Discrimination and diversity in South Africa. Journal of Contemporary African Studies 26(1). 1-25.

Steyn, Melissa. 2004. Rehabilitating a whiteness disgraced: Afrikaner White Talk in postapartheid South Africa. Communication Quarterly 52(2). 143-169.

Steyn, Melissa \& Don Foster. 2008. Repertoires for talking white: Resistant whiteness in postapartheid South Africa. Ethnic and Racial Studies 31(1). 25-51.

Tate, William. 1997. Critical Race Theory and Education: History, Theory and Implications. Review of Research in Education 22. 195-247.

Twine, France Winddance. \& Charles Gallagher. 2008. Introduction - The future of whiteness: A map of the 'third wave'. Ethnic and Racial Studies 31(1). 4-24.

Walker, Melanie. 2005. Rainbow nation or new racism? Theorizing race and identity formation in South African higher education. Race Ethnicity and Education 8(2). 129146.

\section{Bionote Zannie Bock}

Zannie Bock is Associate Professor at the University of the Western Cape. Her current research publications include work on racializing discourses among university students, emerging styles in youth instant messaging chats, and the ways in which affect and stance are encoded in texts. Earlier publications include discourse analyses of testimonies given before South Africa's Truth and Reconciliation Commission. 